\title{
PENERAPAN PRINSIP TRANSPARANSI DAN AKUNTABILITAS DALAM PELAKSANAAN PELAYANAN PUBLIK DI KELURAHAN ALAI PARAK KOPI KOTA PADANG
}

\author{
Widya Nengsih ${ }^{1}$ \\ Ilmu Administrasi Negara, Fakultas Ilmu Sosial, Universitas Negeri Padang \\ nengsihwidya21@gmail.com \\ M. Fachri Adnan² \\ Ilmu Administrasi Negara, Fakultas Ilmu Sosial, Universitas Negeri Padang \\ fachri.adnan@gmail.com \\ Fitri Eriyanti ${ }^{3}$ \\ Ilmu Administrasi Negara, Fakultas Ilmu Sosial, Universitas Negeri Padang \\ fitri.eriyanti4138@gmail.com
}

\begin{abstract}
This study aims to describe the application of the principles of transparency and accountability in Alai Parak Kopi, Padang City. This study describes service transparency seen from the openness of services, procedures and service requirements that can be understood by the community, ease of access to information and service accountability seen from the suitability of implementation with service procedures, clear legal rules, measurable outputs and outcomes. This research is a descriptive study with a quantitative approach. The population of this study amounted to 12.144 with a sample of 99 respondents determined by the slovin formula and using random sampling techniques. The research instrument was analyzed using a questionnaire with a Likert scale measurement. The data in this study were analyzed by descriptive statistics. The results showed that the application of the principle of transparency in services reached $69.8 \%$ and was categorized as quite transparent, except that there was no information dissemination through print or electronic media. While the application of the principle of accountability in service reaches $67.8 \%$ and is categorized as quite accountable.
\end{abstract}

keywords: transparansi, akuntabilitas, pelayanan publik

\section{Pendahuluan}

Dalam praktik penyelenggaraan pelayanan publik, pemerintah mempunyai peranan yang begitu penting untuk memberikan pelayanan terbaiknya kepada semua masyarakat tanpa adanya diskriminatif sesuai dengan (Undang-Undang Nomor 25 Tahun 2009 tentang Pelayanan Publik, 2009) sebagai berikut : "Pelayanan publik adalah kegiatan atau rangkaian kegiatan dalam rangka pemenuhan kebutuhan pelayanan sesuai dengan peraturan perundangundangan bagi setiap warga negara dan penduduk atas barang, jasa dan / atau pelayanan administratif yang disediakan oleh penyelenggara pelayanan publik" (Pasal 1 Ayat (1)). Dalam memberikan pelayanan

Widya Nengsih, M.Fachri Adnan, Fitri Eriyanti |112 


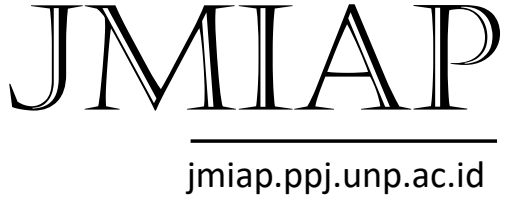

jmiap.ppj.unp.ac.id terbaik oleh penyedia layanan, harus difokuskan kepada pemenuhan kebutuhan masyarakat secara maksimal baik dari segi kualitas maupun kuantitasnya. Seiring dengan perkembangan zaman saat ini, tuntutan akan tata kelola pemerintahan yang baik dan bersih menjadi suatu keharusan dalam sistem pemerintahan saat ini.

Tata kelola pemerintahan yang baik akan terwujud bila dalam praktik penyelenggaraan pelayanan dilakukan dengan baik pula, serta pemerintah harus terbuka atau transparan dan juga bertanggungjawab untuk memberikan pelayanan terbaiknya demi terwujudnya praktik pelayanan yang transparan dan akuntabel. Hal ini sesuai dengan (Keputusan Menteri Pendayagunaan Aparatur Negara Nomor: KEP/26/M.PAN/2004 tentang Petunjuk Teknis Tranparansi dan Akuntabilitas dalam Penyelenggaraan Pelayanan Publik, 2004) dijelaskan bahwa prosedur pelayanan harus sederhana, tidak berbelit-belit, mudah untuk dipahami dan diwujudkan dalam bentuk alur yang dipajang pada ruang pelayanan. Kemudian untuk rincian biaya pelayanan dan waktu pelayanan harus diinformasikan secara jelas dan dicetak sesuai kondisi ruangan serta pemerintah dapat mempertanggungjawabkan apa-apa saja kegiatan yang telah dilaksanakan baik kepada publik maupun kepada atasan/unit pelayanan sesuai dengan peraturan perundang-undangan.

Kelurahan sebagai tingkat paling rendah dalam struktur pemerintahan, seharusnya dapat memberikan pelayanan terbaik kepada masyarakat serta dalam memperlihatkan kinerja yang baik pula.Kelurahan Alai Parak Kopi merupakan salah satu kelurahan yang melaksanakan praktik penyelenggaraan pelayanan publik. Jenis pelayanan yang biasa dilakukan di Kelurahan Alai Parak Kopi diantaranya yaitu pengantar pembuatan
Kartu Keluarga (KK), surat keterangan pindah, pengantar pembuatan akte kelahiran, surat keterangan kematian, surat pengantar Kartu Tanda Penduduk (KTP), surat keterangan izin usaha, surat tinggal sementara, surat pengantar pembuatan SKCK, surat keterangan tidak mampu, surat keterangan untuk menikah, surat permohonan keramaian, surat keterangan IMB, surat keterangan ahli waris, dll.

Dalam Praktik penyelenggaraan pelayanan terkait dengan transparansi dan akuntabilitas di Kelurahan Alai Parak Kopi belum berjalan begitu baik. Transparansi pelayanan di Kelurahan Alai Parak Kopi belum maksimal bisa dilihat dari belum adanya penyebaran informasi melalui media baik itu media cetak ataupun media elektronik. Kemudian terkait dengan biaya pengurusan surat-surat yang kurang jelas, dikatakan "semua biaya administrasi harus sesuai peraturan dan bebas dari pungutan liar (pungli)". Namun kenyataannya berbeda masih terdapat pemberian imbalan kepada pegawai kelurahan.kemudian juga masih kurangnya sarana dan prasarana pendukung dalam pelayanan.

Selain keterbukaan dalam pelayanan, pelayanan yangt akuntabel juga diperlukan dalam praktik penyelenggaraan pelayanan publik.Kelurahan Alai Parak Kopi belum berjalan dengan baik dalam hal mempertanggungjawabkan segala kegiatan pelayanan yang dilaksanakan. Salah satunya dapat dilihat dari tidak dapat melihatkan arsip yang ada di Kelurahan dengan alasan terbuangnya arsip pada saat kegiatan bersihbersih. Kemudian juga tidak adanya punishment atau sangsi bagi pegawai apabila terdapat kesalahan dalam pelayanan.

Berdasarkan latar belakang masalah diatas, penulis telah melaksanakan penelitian di Kelurahan Alai Parak Kopi Kota Padang tentang Penerapan Prinsip Transparansi Dan 


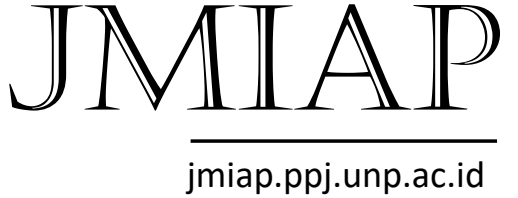

jmiap.ppj.unp.ac.id
Akuntabilitas Dalam Pelaksanaan Pelayanan Publik Di Kelurahan Alai Parak Kopi Kota Padang. Rumusan masalah terletak pada : 1) Bagaimanakah penerapan prinsip transparansi dalam pelaksanaan pelayanan publik di Kelurahan Alai Parak Kopi Kota Padang ?, 2) Bagaimanakah penerapan prinsip akuntabilitas dalam pelaksanaan pelayanan publik di Kelurahan Alai Parak Kopi Kota Padang ? 3) Faktor yang mempengaruhi penerapan prinsip transparansi dan akuntabilitas dalam pelaksanaan pelayanan publik di Kelurahan Alai Parak Kopi Kota Padang?.

\section{Metode Penelitian}

Jenis penelitian ini adalah penelitian deskriptif dengan menggunakan metode kuantitatif. Dikatakan pendekatan kuantitatif dikarenakan pendekatan yang digunakan didalam penelitian, turun kelapangan, analisa data menggunakan aspek pengukuran, perhitungan, rumus. Penelitian ini dilakukan selama tiga bulan dan penelitian dilakukan di Kantor Kelurahan Alai Parak Kopi Kota Padang. Populasi dalam penelitian ini berjumlah 12.144 dengan sampel penelitian yang terdiri dari 99 responden yang ditentukan menggunakan rumus Slovin dengan tingkat kesalahan 10\% dan teknik penentuan sampel dilakukan dengan teknik Random Sampling. Pengumpulan data dalam penelitian ini dilakukan dengan menggunakan angket dengan pengukuran skala likert dan menggunakan 4 opsi jawaban (sangat setuju, setuju, tidak setuju, sangat tidak setuju. Data yang diperoleh dianalisis dengan menggunakan mean (rata-rata) dan Tingkat Capaian Responden (TCR)

\section{Tinjauan Kepustakaan}

\section{Transparansi Dalam Pelaksanaan Pelayanan Publik}

Dalam Praktik penyelenggaraan pelayanan publik, transparansi atau keterbukaan dalam pelayanan sangat penting sehingga dapat terwujudnya pelayanan yang transparan. Menurut (Dwiyanto, 2014) transparansi diartikan sebagai penyediaan informasi tentang pemerintahan bagi publik dan dijaminnya kemudahan didalam memperoleh informasi-informasi yang akurat dan memadai. Pendapat lain tentang pengertian transparansi yaitu menurut (Adisasmita, 2011) transparansi itu berarti keterbukaan pemerintahan dalam memberikan informasi yang terkait dengan aktivitas pengelolaan sumber daya publik kepada pihak-pihak yang membutuhkan informasi. Selain itu menurut (Hamid, 2007) transparansi adalah keterbukaan atas semua tindakan dan kebijakan yang diambil oleh pemerintah.

Dari beberapa pengertian transparansi menurut para ahli dapat disimpulkan bahwa transparansi ialah penyediaan informasi tentang aktivitas penyelenggaran pemerintahan yang harus disertai dengan mudahnya masyarakat untuk dapat mengetahui suatu informasi tertentu secara benar. Transparansi masih menjadi "barang mewah" sehingga tidak semua orang bisa menikmatinya.Padahal transparansi menjadi salah satu prinsip yang penting dari pelaksanaan pelayanan publik yang berkualitas. Pemerintahan dinilai baik buruknya, salah satunya ditentukan oleh tingkat transparansi didalam pemerintahannya (Dwiyanto, 2014).

Untuk mengetahui seberapa jauh penerapan prinsip transparansi dalam proses pelaksanaan pelayanan publik, dapat diukur dengan indikator-indikator transparansi. (Dwiyanto, 2014) mengemukakan indikator transparansi diantaranya yaitu : 1). Mengukur tingkat keterbukaan proses penyelenggaraan pelayanan publik, 2) 
Seberapa mudah peraturan dan prosedur pelayanan dapat dipahami oleh pengguna layanan dan stakeholder lainnya, 3) Kemudahan untuk memperoleh informasi mengenai berbagai aspek penyelenggaraan pelayanan publik. Pendapat lain yang juga mengemukakan tentang indikator dari transparansi yaitu menurut (Hamid, 2007) bahwa keberhasilan transparansi dapat dilihat dari beberapa indikator diantaranya yaitu : a). Meningkatnya keyakinan dan kepercayaan publik kepada institusi bahwa institusi adalah bersih dan berwibawa, b) Meningkatnya partisipasi publik dalam penyelenggaraan institusi, c) Bertambahnya wawasan dan pengetahuan publik terhadap penyelenggaraan institusi, d) Berkurangnya pelanggaran terhadap peraturan perundangundangan yang berlaku.

Transparansi atau keterbukaan dalam proses penyelenggaraan pelayanan publik harus bisa diterapkan dengan baik sesuai dengan indikator-indikator tertentu yang dapat mengukur sejauh mana prinsip transparansi sudah dilaksanakan dalam praktik pelayanan publik. Apabila penerapan prinsip transparansi sudah sesuai dengan indikator maka dapat dikatakan bahwa penerapan transparansinya sudah baik dan dapat mewujudkan suatu tata pemerintahan yang baik atau pemerintahan yang transparan.

\section{Akuntabilitas Dalam Pelaksanaan Pelayanan Publik}

Selain dari penerapan transparansi, penerapan akuntabilitas dalam pelaksanaan pelayanan publik juga sangat penting. Pengertian akuntabilitas Menurut (Mardiasmo, 2006) adalah suatu bentuk kewajiban mempertanggungjawabkan keberhasilan atau kegagalan pelaksanaan misi organisasi dalam mencapai tujuan dan sasaran yang telah ditetapkan sebelumnya, melalui suatu media pertanggungjawaban yang dilaksanakan secara periodik. Selain itu, Menurut Budiarjo (Sutedi, 2009) menjelaskan bahwa Akuntabilitas adalah sebagai suatu pertanggungjawaban pihak yang diberi mandat untuk memerintah kepada mereka yang memberi mandat itu. Ada juga pengertian akuntabilitas menurut (Ndraha, 2003) tanggung jawab sebagai asas berarti, bukan saja setiap aktor pemerintahan bertanggungjawab atas pelaksanaan tugas dan kewajibannya, tetapi lebih-lebih lagi : tiada suatu peristiwa pemerintahan pun yang terjadi tanpa seseorang yang bertanggungjawab atasnya. Harus ada yang bertanggung jawab atas setiap peristiwa pemerintahan. Dari beberapa pemaparan menurut para ahli mengenai pengertian akuntabilitas, dapat disimpulkan bahwa akuntabilitas yaitu suatu kewajiban atau tanggungjawab dari individu atau sekelompok orang (organisasi) yang telah mendapatkan mandat untuk menyampaikan pertanggungjawabannya kepada stakeholders atau pihak-pihak yang berkepentingan.

Untuk mengetahui sejauh mana penerapan prinsip akuntabilitas dalam proses pelaksaaan pelayanan publik maka dapat dilihat dari beberapa indikator akuntabilitas yang dikemukakan oleh Menurut (Solihin, 2007) indikator minimum akuntabilitas yaitu : 1)Adanya kesesuaian antara pelaksanaan dengan standar prosedur pelaksanaan, 2) Adanya sangsi yang ditetapkan atas kesalahan atau kelalaian dalam pelaksanaan kegiatan, 3) Adanya output dan outcome yang terukur. Untuk mendukung indikator minimal akuntabilitas yang dikemukakan oleh (Solihin, 2007) tersebut ada perangkat pendukung indikator minimum akuntabilitas yaitu : a) Adanya Standart Operating Procedure (SOP) dalam penyelenggaraan kebijakan, b)Mekanisme pertanggungjawaban, c)Laporan tahunan, 


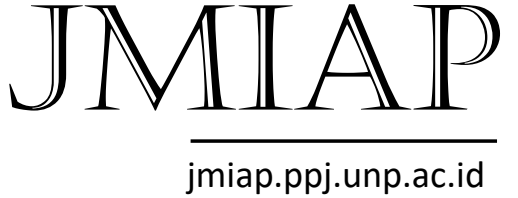

d)Sistem pemantauan kinerja penyelenggara Negara e)Sistem pengawasan, f). Mekanisme reward dan punishment. Selain itu, (Surjadi, 2009) merincikan bahwa akuntabilitas pelayanan publik terdiri dari 6 kinerja : 1) Akuntabilitas kinerja pelayanan publik, 2)Sesuai dengan standar pelayanan atau janji pelayanan, 3)Dapat dipertanggungjawabkan secara terbuka (transparan) baik kepada public, 4)Penyimpangan yang terkait dengan akuntabilitas kinerja pelayanan publik diberikan kompensasi kepada penerima layanan, 5)Tersedianya mekanisme pertanggungjawaban apabila terjadi kerugian dalam pelayanan publik.

\section{HASIL DAN PEMBAHASAN}

Dalam bagian ini akan dijelaskan hasil penelitian dan pembahasan dari penerapan prinsip transparansi dan akuntabilitas dalam pelaksanaan pelayanan publik di Kelurahan Alai Parak Kopi sebagai berikut :

\section{Penerapan Prinsip Transparansi Dalam Pelaksanaan Pelayanan Publik}

Sebagaimana yang telah dijelaskan pada bagian pendahuluan. Dalam penelitian ini akan menjawab dua item pertanyaan penelitian yang terdapat dalam rumusan masalah. Berikut ini hasil analisis data yang akan menjawab rumusan pertama yang disajikan dalam bentuk tabel sebagai berikut

Tabel 1. Penerapan Prinsip Transparansi Dalam Pelaksanaan Pelayanan

$\begin{array}{llll}\text { No } & \begin{array}{l}\text { Indikator } \\ \text { variabel }\end{array} & \text { Rata- } & \text { TCR } \\ & \text { rata } \\ & \text { skor } \\ & & \\ & & \text { (mean) } & \end{array}$

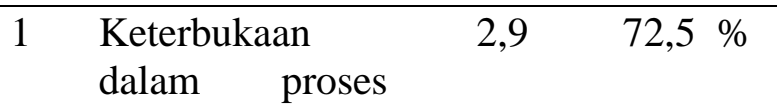

JURNAL ILMU ADMINISTRASI PUBLIK

Email : jianfis.unp@gmail.com

Vol.2 No.1 Maret 2019

\begin{tabular}{|c|c|c|c|}
\hline & pelayanan & & \\
\hline 2 & $\begin{array}{ll}\text { Prosedur dan } \\
\text { persyaratan } \\
\text { dipahami oleh } \\
\text { masyarakat }\end{array}$ & 2,81 & $70,25 \%$ \\
\hline 3 & $\begin{array}{l}\text { Mudahnya } \\
\text { memperoleh } \\
\text { informasi } \\
\text { pelayanan }\end{array}$ & 2,6 & $66,75 \%$ \\
\hline
\end{tabular}

\begin{tabular}{lll}
\hline Rata-rata & $\mathbf{2 , 7 7}$ & $\mathbf{6 9 , 8 3 \%}$
\end{tabular}

Sumber : Hasil Pengolahan Data 2018

Berdasarkan data pada tabel 1 diatas dapat diketahui bahwa penerapan prinsip transparansi dalam pelaksanaan pelayanan publik di Kelurahan Alai Parak Kopi Kota Padang yaitu sebesar 69,83\% yang berarti cukup baik berdasarkan pada standar pengkategorian nilai TCR menurut (Arikunto, 2010). Perhitungan tersebut diperoleh dari rata-rata : a) keterbukaan dalam proses pelayanan yaitu nilai mean atau rata skor sebesar 2,9 dan nilai TCR sebesar $72.5 \%$ dinyatakan cukup baik, b) prosedur dan persyaratan dipahami oleh masyarakat yaitu nilai mean atau rata skor sebesar 2,81 dan nilai TCR sebesar 70.25\% dinyatakan cukup baik, c) mudahnya memperoleh informasi pelayanan yaitu nilai mean atau rata skor sebesar 2,6 dan nilai TCR sebesar $66.75 \%$ dinyatakan cukup baik.

\section{Penerapan Prinsip Akuntabilitas Dalam Pelaksanaan Pelayanan Publik}

Sebagaimana yang telah dijelaskan pada bagian pendahuluan diatas, maka berikut ini hasil analisis data yang akan menjawab rumusan kedua yang disajikan dalam bentuk tabel 2 sebagaimana dijelaskan sebagai berikut :

\section{Tabel 2. Penerapan Prinsip Akuntabilitas Dalam Pelaksanaan Pelayanan}




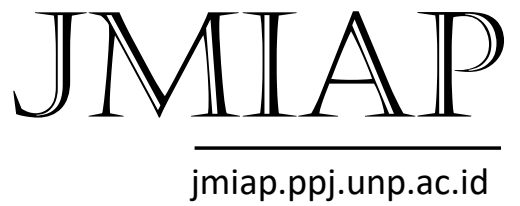

jmiap.ppj.unp.ac.id

\begin{tabular}{llll}
\hline No & $\begin{array}{l}\text { Indikator } \\
\text { variabel }\end{array}$ & $\begin{array}{l}\text { Rata- } \\
\text { rata } \\
\text { skor } \\
\end{array}$ & TCR \\
& & (mean) & \\
& & &
\end{tabular}

\begin{tabular}{|c|c|c|c|}
\hline 1 & $\begin{array}{l}\text { Kesesuaian } \\
\text { antara } \\
\text { pelaksanaan } \\
\text { dengan prosedur } \\
\text { pelayanan }\end{array}$ & 3.11 & $\begin{array}{c}77.75 \\
\%\end{array}$ \\
\hline 2 & $\begin{array}{l}\text { Adanya aturan } \\
\text { hukum } \\
\text { jelas }\end{array}$ & 2.4 & $60,25 \%$ \\
\hline 3 & $\begin{array}{l}\text { Output dan } \\
\text { outcome yang } \\
\text { terukur }\end{array}$ & 2,6 & $65.41 \%$ \\
\hline
\end{tabular}

\begin{tabular}{lll}
\hline Rata-rata & 2,7 & $\mathbf{6 7 . 8 0 \%}$
\end{tabular}

Sumber : Hasil Pengolahan Data 2018

Berdasarkan data pada tabel 2 diatas dapat dipahami bahwa penerapan prinsip akuntabilitas dalam pelaksanaan pelayanan publik di Kelurahan Alai Parak Kopi Kota Padang yaitu sebesar $67.80 \%$ yang berarti cukup baik berdasarkan pada standar pengkategorian nilai TCR menurut (Arikunto, 2010). Perhitungan tersebut diperoleh dari rata-rata : a) Kesesuaian antara pelaksanaan dengan prosedur pelayanan yaitu nilai mean atau rata skor sebesar 3.11 dan nilai TCR sebesar $77.75 \%$ dinyatakan cukup baik, b) Adanya aturan hukum yang jelas yaitu nilai mean atau rata skor sebesar 2.4 dan nilai TCR sebesar $60.25 \%$ dinyatakan tidak baik, c) Output dan outcome yang terukur yaitu nilai mean atau rata skor sebesar 2,6 dan nilai TCR sebesar $65.41 \%$ dinyatakan cukup baik.

\section{Pembahasan}

Penerapan Prinsip Transparansi
Pelayanan

Untuk menganalisis penerapan prinsip transparansi pada pelaksanaan pelayanan publik di Kelurahan Alai Parak Kopi Kecamatan Padang Utara, diukur menggunakan beberapa indikator transparansi sebagaimana dikemukakan oleh (Dwiyanto, 2014). Berikut akan dijelaskan per indikator yang berkaitan dengan transparansi pelayanan :

\section{a. Keterbukaan Dalam Proses Pelayanan Publik}

Di Kelurahan Alai Parak Kopi Kota Padang terkait keterbukaan dalam proses pelayanan publik cukup baik. Di tandai dengan cukup cepatnya waktu pelayanan dan biaya pelayanan yang gratis meskipun terkadang masih terdapat pemberian "imbalan" yang diberikan oleh masyarakat kepada pegawai kelurahan.

Dilihat dari penelitian sebelumnya yang serupa oleh (Nining, 2016) tentang Akuntabilitas dan Transparansi Dalam Pelayanan Publik (Studi Pembuatan SIM) di Satlantas Makassar. Hasil penelitian menunjukkan bahwa masih lamanya waktu pelayanan dan masih adanya biaya ekstra yang harus dikeluarkan oleh masyarakat dan juga ada pemberian imbalan atas bantuan yang telah diberikan serta pelayanan masih bersifat deskriminasi.Berdasarkan hasil penelitian diatas sesuai dengan pendapat yang dikemukakan oleh (Dwiyanto, 2014) dimana dalam keterbukaan proses pelayanan publik bisa dilihat dari semakin cepatnya waktu pelayanan dan biaya yang jelas maka pelayanan dapat dinilai memliki transparansi yang tinggi. Menurut (Keputusan Menteri Pendayagunaan Aparatur Negara Nomor: KEP/26/M.PAN/2004 tentang Petunjuk Teknis Tranparansi dan Akuntabilitas dalam Penyelenggaraan Pelayanan Publik, 2004) di jelaskan bahwa kepastian jangka waktu pelayanan publik harus diinformasikan 
secara jelas dan diletakkan diruang pelayanan dan kepastian rincian biaya pelayanan yang jelas serta setiap pungutan yang ditarik harus disertai dengan tanda bukti resmi.

\section{b. Prosedur Dan Persyaratan Pelayanan Dapat Dipahami Masyarakat}

Di Kelurahan Alai Parak Kopi terkait prosedur dan persyaratan pelayanan cukup dipahami oleh masyarakat ditandai dengan sudah adanya pemajangan berbagai persyaratan dan prosedur pelayanan sehingga masyarakat bisa memahami apaapa saja yang menjadi persyaratan pelayanan.

Dilihat dari penelitian sebelumnya yang serupa oleh (Chandra, 2016) tentang Penerapan Prinsip Good Governance Dalam Pelaksanaan Pelayanan Publik Di Kantor Camat Siluq Kutai Barat.Hasil penelitian menunjukkan bahwa penerapan prinsip good governance khususnya prinsip transparansi dan akuntabilitas sudah berjalan dengan baik dapat dilihat dari sudah adanya prosedur yang jelas, persyaratan yang mudah dipahami oleh masyarakat.

Berdasarkan hasil penelitian diatas sesuai dengan pendapat yang dikemukakan oleh (Dwiyanto, 2014) terkait dengan prosedur dan persyaratan yang dapat dipahami oleh masyarakat dapat dilihat dari prosedur dan persyaratan yang ditetapkan.Bila prosedur dan persyaratan pelayanan bersifat rasional, simpel serta mudah dipahami oleh pengguna, maka semakin tinggi pula penerapan prinsip transparansi yang telah dilaksanakan. Menurut (Ratminto Winarsih, 2010) untuk mendapatkan pelayanan, pengguna harus memenuhi persyaratan yang telah ditetapkan oleh Pemberi layanan baik persyaratan teknis maupun administratif. Penetapan persyaratan dan prosedur pelayanan harus seminimal mungkin agar benar-benar sesuai dengan jenis pelayanan yang akan diberikan.

Menurut (Keputusan Menteri Pendayagunaan Aparatur Negara Nomor: KEP/26/M.PAN/2004 tentang Petunjuk Teknis Tranparansi dan Akuntabilitas dalam Penyelenggaraan Pelayanan Publik, 2004) dikatakan bahwa prosedur pelayanan harus sederhana, mudah dipahami serta persyaratan yang ditetapkan sesuai dengan Undang-Undang dan diwujudkan dalam bentuk bagan yang dipajang dalam ruangan pelayanan.

\section{c. Mudahnya Untuk Memperoleh Informasi Pelayanan}

Di Kelurahan Alai Parak Kopi Kemudahan untuk memperoleh informasi pelayanan cukup baik ditandai dengan adanya papan informasi berbagai macam pelayanan yang dipajang pada ruang pelayanan hanya saja belum ada pempublikasian informasi pelayanan melalui media baik media cetak ataupun elektronik.

Dilihat dari penelitian sebelumnya yang serupa oleh (Syamsinar, 2016) tentang Penerapan Prinsip Tata Pemerintahan Yang Baik Dalam Pelayanan Publik Di Kelurahan Baqa Kota Samarinda.Hasil penelitian menunjukkan bahwa penerapan prinsip transparansi sudah cukup baik dapat dilihat dengan sudah mengedepankan aspek-aspek keterbukaan dan keterlibatan masyarakat dalam menentukan skala prioritas pelayanan.

Berdasarkan hasil penelitian diatas sesuai dengan pendapat yang dikemukakan oleh (Dwiyanto, 2014) terkait kemudahan untuk memperoleh informasi pelayanan dapat dilihat dari adanya pemajangan seluruh informasi pelayanan.Bila informasi pelayanan baik sebagian maupun keseluruhan dari informasi pelayanan masih 
belum terbuka dan informasinya masih sulit didapatkan oleh masyarakat, maka praktik pelayanan belum memenuhi kaedah transparansi itu sendiri dan begitu sebaliknya. Menurut (Undang-Undang No 14 Tahun 2008 tentang Keterbukaan Informasi Publik, 2008) menjelaskan bahwa setaip orang berhak untuk memperoleh informasi, kewajiban Pelayan Publik harus dapat menyedaikan informasi secara cepat, tepat waktu, sederhana, serta membenahi sistem pelayanan informasi. Menurut (Keputusan Menteri Pendayagunaan Aparatur Negara Nomor: KEP/26/M.PAN/2004 tentang Petunjuk Teknis Tranparansi dan Akuntabilitas dalam Penyelenggaraan Pelayanan Publik, 2004) dikatakan bahwa semua informasi pelayanan yang dibutuhkan oleh masyarakat, setiap instansi wajib mempublikasikan informasi pelayanan melalui media cetak, elektronik, gambar maupun mensosialisasikan langsung pada pengguna.

\section{Penerapan Prinsip Akuntabilitas Pelayanan}

Untuk menganalisis penerapan prinsip akuntabilitas pada pelaksanaan pelayanan publik di Kelurahan Alai Parak Kopi Kecamatan Padang Utara, diukur menggunakan beberapa indikator akuntabilitas sebagaimana dikemukakan oleh (Solihin, 2007). Berikut akan dijelaskan per indikator yang berkaitan dengan akuntabilitas pelayanan :

\section{a. Kesesuaian antara pelaksanaan pelayanan dengan prosedur pelayanan}

Terkait pelaksaan pelayanan dengan prosedur pelayanan yang diselenggarakan di Kelurahan Alai Parak Kopi cukup sesuai di tandai sudah berpedomannya kepada (Undang-Undang Nomor 25 Tahun 2009 tentang Pelayanan Publik, 2009) yang dipajang diruangan pelayanan serta sudah memiliki alur pelayanan yang cukup jelas.Berdasarkan hasil penelitian diatas sesuai dengan pendapat yang dikemukakan oleh (Solihin, 2007) dikatakan bahwa dalam praktik penyelenggaraan pelayanan publik harus memiliki standar pelayanan atau Standart Operating Procedure (SOP).Jika pelaksanaan sesuai dengan prosedur pelayanan maka masyarakat mudah untuk memperoleh pelayanan dan juga semakin tinggi pula akuntabilitas pelayanan yang sudah dipraktikkan.

Menurut (Surjadi, 2009) mengemukakan bahwa akuntabilitas dalam praktik penyelenggaraan pelayanan publik yang dilakukan haruslah akurat baik dari tingkat ketelitian pelayanan, profesionalitas dan sesuai dengan standar pelayanan atau janji pelayanan yang telah ditetapkan sebelumnya.

\section{b. Adanya aturan hukum atas penyelenggaraan pelayanan}

Dalam praktik penyelenggaraan pelayanan publik di Kelurahan Alai Parak Kopi belum adanya tanggung jawab dari pegawai apabila terdapat kesalahan dalam proses pelayanan. Seharusnya dalam praktik pelayanan di Kelurahan Alai Parak Kopi sudah menetapkan aturan hukum baik berupa reward atau penghargaan dan juga punishment bagi pegawai yang melakukan kelalaian atau kesalahan dalam pelayanan.

Dilihat dari penelitian sebelumnya yang serupa oleh (Syamsinar, 2016) tentang Penerapan Prinsip Tata Pemerintahan Yang Baik Dalam Pelayanan Publik Di Kelurahan Baqa Kota Samarinda.Hasil penelitian menunjukkan bahwa penerapan prinsip akuntabilitas sudah terlaksana dengan baik.Hal ini tercermin dari tersedianya kotak saran yang disediakan oleh pihak Kelurahan 
dan sudah adanya penyampaian keluhan secara lansung kepada RT.

Berdasarkan hasil penelitian diatas sesuai dengan pendapat yang dikemukakan oleh (Solihin, 2007) dikatakan bahwa terkait dengan adanya aturan hukum dalam proses pelayanan publik dapat dilihat dari adanya penerapan sistem reward and punishment. Bila sistem seperti ini sudah diterapkan maka bisa meminimalisir untuk terjadinya kesalahan dalam pelayanan dan semakin tinggi pula praktik dari akuntabilitas pelayanan. (Surjadi, 2009) mengemukakan bahwa dalam praktik penyelenggaraan pelayanan terkait dengan akuntabilitas harus tersedianya mekanisme pertanggungjawaban apabila terjadi kerugian dalam pelayanan publik, atau bila ada keluhan atau pengaduan dari masyarakat tidak mendapatkan tanggapan sesuai dengan waktu yang telah ditetapkan.

\section{c. Output Dan Outcome Yang Terukur}

Hasil (output) dari pelayanan yang diselenggarakan cukup jelas, dimana bila mengurus kartu keluarga, pabila syarat sudah lengkap, maka masyarakat dapat memperoleh surat pengantar pembuatan KK. Selain itu ada output berupa program yang diselenggarakan di Kelurahan Alai Parak Kopi cukup sesuai dengan harapan masyarakat namun begitu masih ada program yang belum tepat sasarannya dan perlu untuk dilakukan evaluasi yang rutin.

Berdasarkan hasil penelitian diatas sesuai dengan pendapat yang dikemukakan oleh (Solihin, 2007) dikemukakan bahwa terkait adanya output dan outcome yang terukur dalam proses pelayanan publik dilihat dari adanya program-program tertentu yang orientasinya demi kepentingan dari masyarakat bukan kepentingan dari kelompok tertentu. Apabila dalam praktik penyelenggaraan pelayanan berupa program (output) sudah sesuai harapan masyarakat maka semakin tinggi pula akuntabilitas pelayanannya.

Faktor yang mempengaruhi transparansi dan akuntabilitas dalam pelaksanaan pelayanan publik di Kelurahan Alai Parak Kopi

Faktor yang mempengaruhi transparansi pelayanan publik

Dalam praktik penyelenggaraan pelayanan publik di Kelurahan Alai Parak Kopi Kota Padang, menurut (Wiharto, 2011) ada beberapa faktor- faktor yang mempengaruhi penerapan prinsip transparansi dalam pelayanan publik di antaranya yaitu :

Faktor pendorong transparansi pelayanan publik di Kelurahan Alai Parak Kopi Kota Padang

Pertama, profesionalisme Sumber Daya Manusia. Ini merupakan salah satu faktor pendorong untuk terciptanya pelayanan publik yang transparan. Pegawai yang selalu menjaga profesionalismenya seharusnya diberikan reward atau penghargaan terhadap kinerja terbaik yang telah dilakukan selama dalam proses pelayanan publik. Kelurahan Alai Parak Kopi belum ada menerapkan sistem reward terhadap pegawai yang memiliki profesionalisme yang cukup baik dalam memberikan pelayanan kepada masyarakat. Tidak adanya reward khusus dari kelurahan tersebut, pegawainya telah mendapatkan tunjangan diluar gaji pokok dari Pemerintah.

Kedua, ketepatan sistem atau aturan.Ini merupakan salah satu faktor yang mendorong dalam penerapan prinsip transparansi di Kelurahan Alai Parak Kopi Kota Padang.Aturan dalam penyelenggaraan pelayanan di Kelurahan Alai Parak Kopi Kota Padang sudah berpedoman kepada (Undang-Undang Nomor 25 Tahun 2009 tentang Pelayanan Publik, 2009). Setiap 


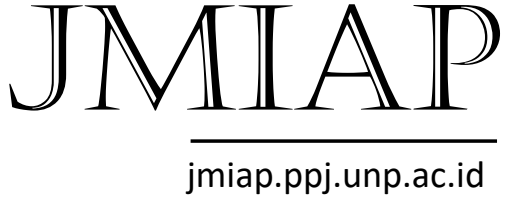

jmiap.ppj.unp.ac.id jenis pelayanan administratif kependudukan, prosedur dan persyaratan pelayanan publik yang dilaksanakan di Kelurahan Alai Parak Kopi sudah berpatokan pada UU tersebut.Jenis pelayanan nya sudah jelas, waktu penyelesaiannya cukup cepat, prosedur pelayanan yang jelas dan persyaratan pelayanan mudah dipahami.Hal ini jelas dapat mendorong untuk terciptanya suatu pelayanan publik yang transparan.

Ketiga, persaingan lingkungan yang sehat. Persaingan diantara pemerintah daerah untuk meningkatkan kinerja (pelayanan publik) untuk menciptakan pemerintah yang transparan dilakukan dengan selalu memperbaiki pelayanan dengan cara menerima masukan dari masyarakat karena masyarakat sebagai pengguna layanan. Kelurahan Alai Parak Kopi Kota Padang cukup baik dalam melakukan koordinasi dengan instansi Pemerintah yang terkait untuk peningkatan pelayanan di Kelurahan sesuai dengan visi misi yang ada di Kelurahan Alai Parak Kopi Kota Padang.Hal ini dapat mendorong untuk terwujudnya penyelenggaraan pelayanan prima.

Faktor penghambat transparansi dalam pelaksanaan pelayanan publik di Kelurahan Alai Parak Kopi Kota Padang

Pertama, Kurangnya profesionalisme SDM atau bermental korup. Dalam praktik penyelenggaraan pelayanan di Kelurahan Alai Parak Kopi yang mana SDM nya kurang kompeten atau bermental korup, masih terdapat pungli atau imbalan dalam proses pelayanan publik. meskipun sudah ada himbauan yang ditempel pada dinding ruangan, tapi masih saja terdapat sistem pelayanan yang tidak sehat. Hal ini jelas dapat menghambat penerapan prinsip transparansi dalam pelaksanaan pelayanan publik.

Kedua, keterbatasan sarana dan prasarana menjadi salah satu faktor yang menghambat untuk terciptanya suatu pelayanan yang terbuka atau transparan.Di Kelurahan Alai Parak Kopi Kota Padang masih minim sarana pendukung dalam penyelenggaraan pelayanan.Pada ruangan Kelurahan terdapat 2 komputer dan hanya 1 komputer yang dapat dioperasikan.Kemudian pendingin ruangan hanya terdapat 1 kipas angin, kemudian lemari arsip yang sudah rapuh.Terkadang arsip hanya ditaruh dilantai ruangan dibawah meja pegawai. Keterbatasan sarana pendukung dalam pelayanan maka dapat menghambat proses penyelenggaraan pelayanan di Kelurahan Alai Parak Kopi Kota Padang.

Ketiga kurangnya pemahaman masyarakat sekitar.Masyarakat yang kurang paham dengan birokrasi mereka hanya pasrah kepada petugas. Masyarakat sudah terbiasa dengan penyimpangan yang terjadi dalam proses pelayanan publik. Masyarakat di Kelurahan Alai Parak Kopi Kota Padang sudah terbiasa dengan adanya penyimpangan misalnya sogok menyogok dalam pelayanan. Kurangnya pemahaman masyarakat tentang birokrasi inilah maka mereka hanya pasrah apa kata pegawai saja. hal ini dapat menghambat untuk terciptanya suatu proses penyelenggaraan pelayanan publik yang transparan.

\section{Faktor yang mempengaruhi akuntabilitas pelayanan publik}

Dalam praktik penyelenggaraan pelayanan publik di Kelurahan Alai Parak Kopi Kota Padang, menurut (Adisasmita, 2011) ada beberapa faktor- faktor yang mempengaruhi penerapan prinsip akuntabilitas dalam pelayanan publik di antaranya yaitu :

Faktor pendorong akuntabilitas pelayanan publik di Kelurahan Alai Parak Kopi Kota Padang

Pertama, dapat diterima oleh semua pihak merupakan salah satu faktor pendorong untuk terciptanya akuntabilitas dalam 


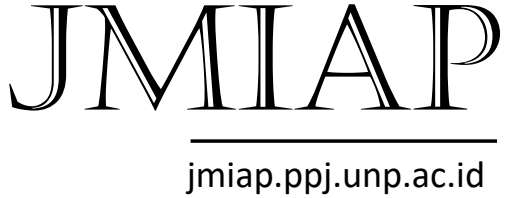

pelaksanaan pelayanan publik.Tujuan dan makna dari akuntabilitas harus dikomunikasikan secara terbuka kepada semua pihak sehingga standard dan aturannya dapat diterima oleh semua pihak. Di Kelurahan Alai Parak Kopi Kota Padang ada standar dan aturan dalam penyelenggaraan pelayanan publik yang sesuai dengan Undang-undang yang berlaku yaitu (Undang-Undang Nomor 25 Tahun 2009 tentang Pelayanan Publik, 2009) dan standar aturan tersebut dapat diterima oleh masyarakat di Kelurahan Alai Parak Kopi Kota Padang.

Kedua, kepemimpinan yang kompeten.Ini merupakan salah satu faktor yang dapat mendorong untuk terciptanya suatu penyelenggaraan pelayanan publik yang akuntabel.Diperlukan Pemimpin yang bertanggungjawab baik kepada bawahan dan juga kepada masyarakat.Di Kelurahan Alai Parak Kopi Kota Padang, Lurahnya cukup baik dalam mempertanggungjawabkan segala kegiatan yang dilaksanakan di Kelurahan.hal ini harus selalu dilakukan agar dapat menwujudkan suatu pelayanan yang akuntabel.

Ketiga, perlu pemahaman masyarakat.Hal ini merupakan salah satu faktor pendorong untuk bisa menciptakan suatu pelayanan yang akuntabel. Setiap kegiatan yang akan dilaksanakan perlu dikomunikasikan dengan masyarakat yang nantinya akan didapatkan suatu kesimpulan dan bagaimana tanggapan dari masyarakat tentang kegiataan tersebut. Di Kelurahan Alai Parak Kopi Kota Padang, kelurahan dan masyarakat sudah menjalin komunikasi cukup baik. apabila akan diadakan suatu kegiatan, maka kelurahan dan masyakat melakukan suatu rapat agar sama-sama mengetahui apakah kegiatan tersebut dapat dijalankan atau tidak. Hal ini
Email : jianfis.unp@gmail.com

Vol.2 No.1 Maret 2019

dapat mendorong untuk terciptanya pemerintah yang akuntabel.

Faktor penghambat akuntabilitas dalam pelaksanaan pelayanan publik di Kelurahan Alai Parak Kopi Kota Padang

Pertama, ketidakpedulian terhadap hak-hak dan masalah sosial merupakan salah satu faktor yang dapat menghambat untuk terciptanya suatu penyelenggaraan pelayanan publik yang akuntabel. Ketidakpedulian ini cendrung menimbulkan peluang untuk bisa terjadinya malpraktik, pungli, sogok menyogok.Di Kelurahan Alai Parak Kopi Kopi Kota Padang masih terjadi hal sogok menyogok dalam pelayanan publik yang diselenggarakan. Pegawai Kelurahan Alai Parak Kopi juga mengatakan bahwa kami tidak meminta, tetapi bila dikasih kami akan terima saja. hal ini jelas dapat menghambat untuk bisa terciptanya pemerintahan yang akuntabel.

Kedua, sikap saling membiarkan. Ini merupakan salah satu faktor yang dapat menghambat dalam menerapkan akuntabilitas dalam praktik penyelenggaraan pelayanan publik. Demoralisasi manusia akan mudah untuk melakukan pelanggaran terhadap aturan yang ditetapkan. Dengan ini pegawai dapat mencari celah untuk mendapatkan keuntungan dan mengabaikan kepentingan khalayak banyak.Dengan membiarkan tindakan negatif tersebut dan tidak ada pula sangsi yang tegas, maka pemerintah yang akuntabel sulit untuk diciptakan. Di Kelurahan Alai Parak Kopi Kota Padang, pegawai kelurahan masih cuek atau membiarkan bila ada terdapat suatu penyimpangan dalam pelayanan. Di tambah juga dengan tidak ada sangsi yang tegas bila terjadi penyimpangan tersebut.Hal ini justru dapat menghambat untuk terciptanya akuntabilitas dalam pelayanan publik. 


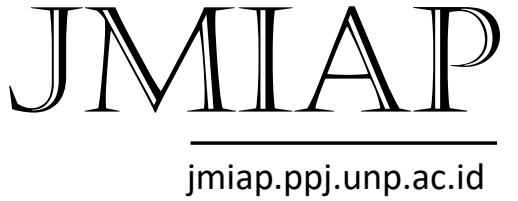

jmiap.ppj.unp.ac.id
Ketiga, faktor budaya.Dalam praktik penyelenggaraan pelayanan publik, samasama diketahui bahwa budaya yang berkembang di lingkungan birokrasi yaitu mementingkan kepentingan pribadi diatas kepentingan masyarakat luas. Akibat dari budaya yang selama ini berkembang yaitu akan menyubukan pertumbuhan KKN di lingkungan pemerintah. Di Kelurahan Alai Parak Kopi Kota Padang, dalam praktik penyelenggaraan pelayanannya, masih ada terdapat budaya mementingkan kepentingan pribadi daripada kepentingan masyarakat. Misal pada jam kerja, ada pegawai yang minta izin sebentar keluar untuk mengurus urusan sekolah anaknya. Padahal tugasnya di kelurahan masih ada.Ini suatu hal yang dapat menghambat untuk terciptanya pemerintah yang akuntabel karena masih mengutamakan kepentingan pribadi daripada kepentingan umum.

\section{KESIMPULAN}

Berdasarkan hasil dan pembahasan di bagian sebelumnya, maka dapat ditarik kesimpulan bahwa :

Pertama, Penerapan prinsip transparansi dalam pelaksanaan pelayanan publik di Kelurahan Alai Parak Kopi Kota Padang dilihat dari indikator Pertama ialah keterbukaan dalam proses pelayanan publik cukup baik, kedua ialah prosedur dan persyaratan pelayanan cukup mudah dipahami masyarakat dan ketiga ialah cukup mudahnya memperoleh informasi pelayanan. Dari ketiga indikator dalam penerapan prinsip transparansi di Kelurahan Alai Parak Kopi cukup transparan, hanya saja belum ada penyebaran atau pempublikasian informasi melalui media baik koran ataupun internet.

Kedua, Penerapan prinsip akuntabilitas dalam pelaksanaan pelayanan publik di Kelurahan Alai Parak Kopi Kota Padang dilihat dari indikator Pertama ialah kesesuaian antara pelaksanaan dengan prosedur nya cukup sesuai.Kedua ialah adanya aturan hukum dalam pelaksanaan pelayanan belum baik. Ketiga ialah adanya output dan outcome yang terukur yang cukup baik. Dalam menganalisis penerapan prinsip akuntabilitas di Kelurahan Alai Parak Kopi cukup akuntabel, hanya saja belum adanya peraturan yang tegas bagi pegawai dalam menyelenggarakan pelayanan baik berupa reward ataupun punishment.

Berdasarkan hasil penelitian dan kesimpulan yang telah diuraikan diatas. Maka penulis dapat memberikan saran-saran sebagai berikut :

Pertama, Kepada Bapak Lurah di Kelurahan Alai Parak Kopi Kecamatan Padang Utara Kota Padang untuk lebih meningkatkan lagi keterbukaan pelayanan dengan cara mempublikasikan informasi pelayanan yang dibutuhkan oleh masyarakat baik melalui media internet maupun koran dan bisa juga melakukan sosialisasi kepada masyarakat.

Kedua, Dalam praktik penyelenggaraan pelayanan publik demi mewujudkan keterbukaan pelayanan, Kelurahan Alai Parak Kopi Kota Padang bisa membuat suatu sistem pelayanan publik dengan cara menerapkan konsep Citizen's Charter (CC) dimana dalam konsep $\mathrm{CC}$ ini menempatkan kepentingan masyarakat sebagai unsur yang paling penting.

\section{DAFTAR PUSTAKA}

Adisasmita, R. (2011). Manajemen

Pemerintahan Daerah. Yogyakarta: Graha Ilmu.

Arikunto. (2010). Prosedur Penelitian Suatu Pendekatan Praktik. Jakarta: Rineka Cipta. 


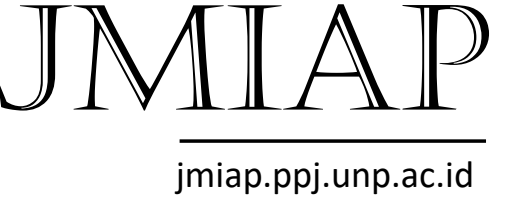

Chandra, E. R. (2016). Penerapan Prinsip Good Governance Dalam Pelaksanaan Pelayanan Publik di Kantor Camat Siluq Ngurai Kabupaten Kutai Barat. EJournal Ilmu Pemerintahan, 4, 570583.

Dwiyanto, A. (2014). Mewujudkan Good Governance Melalui Pelayanan Publik. Yogyakarta: Gadjah Mada University Press.

Hamid, M. (2007). Transparansi dan Lembaga. Jakarta: Sinar Harapan.

Keputusan Menteri Pendayagunaan Aparatur Negara Nomor: KEP/26/M.PAN/2004 tentang Petunjuk Teknis Tranparansi dan Akuntabilitas dalam Penyelenggaraan Pelayanan Publik (2004).

Mardiasmo. (2006). Pewujudan Transparansi dan Akuntabilitas Publik Melalui Akuntansi Sektor Publik: Suatu Sarana Good Governance. Jurnal Akuntansi Pemerintahan, 2, 1-17.

Ndraha, T. (2003). KYBERNOLOGY (Ilmu Pemerintahan Baru). Jakarta: PT. Rineka Cipta.

Nining. (2016). Akuntabilitas dan Transparansi Dalam Pelayanan Publik (Studi Pembuatan SIM) Di Kantor Satlantas Polrestabes Makassar. Jurnal Administrasi Publik, 2, 194-205.

Ratminto Winarsih. (2010). Manajemen Pelayanan : Pengembangan Model Konseptual, Penerapan Citizen's Charter dan Standar Pelayanan Minimal. Jakarta: Pustaka Belajar.

Solihin, D. (2007). Penerapan PrinsipPrinsipGood Governance Dalam Pembangunan Daerah. Jakarta: STIAKIN.
JURNAL ILMU ADMINISTRASI PUBLIK

Email : jianfis.unp@gmail.com Vol.2 No.1 Maret 2019

Surjadi. (2009). Pengembangan Kinerja Pelayanan Publik. Bandung: PT. Rafika Aditama.

Sutedi, A. (2009). Implikasi Hukum Atas Sumber Pembiayaan Daerah Dalam Kerangka Otonomi Daerah. Bandung: PT. Rafika Aditama.

Syamsinar. (2016). Penerapan PrinsipPrinsip Tata Pemerintahan Yang Baik Dalam Pelayanan Publik di Kantor Kelurahan Baqa Kecamatan Samarinda Seberang Kota Samarinda. E-Journal Administrasi Negara, 4, 5161-5173.

Undang-Undang No 14 Tahun 2008 tentang Keterbukaan Informasi Publik (2008).

Undang-Undang Nomor 25 Tahun 2009 tentang Pelayanan Publik (2009).

Wiharto. (2011). Faktor Pendorong Dan Penghambat Terwujudnya Sistem Transparansi Nasional Pelayanan Publik. Yogyakarta. Retrieved from http://semarang.bpk.go.id/ 